\title{
Commuting for Symbolic Capital \\ Narratives of Location and Positionality of Palestinian Refugees
}

By Lene Kofoed Rasmussen

A sense of marginalisation among

Palestinian refugees in Denmark seems to be connected to a lack of recognition of their lifestyle which is diffuse and difficult to cope with. Thus, the pertinence of symbolic capital for emotional forms of belonging is uncovered in transnational practices and narratives on family and gender relations among Palestinian refugees.
$\mathrm{P}$

alestinians form one of the five largest minority groups in Denmark, and the majority of them are refugees from the civil war in Lebanon in the 1980s (Dansk Flygtningehjælp 2004). ${ }^{1}$ Today, many of them engage one way or another in transnational activity, for example, by paying frequent visits, commuting between Denmark and Lebanon, providing for poor family members in Lebanon with regular financial remittances, marrying across borders, or by just keeping in touch through communication and media consumption. According to observations and interviews, some of them consider the option of returning to Lebanon to live, and a few take actual steps to do so. While Lebanese refugees are returning home in great numbers to take part in the rebuilding of the Lebanese society, Palestinians are by no means invited to take on that role in Lebanon. At the same time, the fate of their own nation-state is still unclear, and currently offers no opportunity for refugees to return (Isotalo 2005). 
The data that will be presented and analysed below were collected during a field study among Palestinians who foster transnational connections between Denmark and Lebanon. I carried out interviews and participant observations in Denmark in the beginning of 2002 and in Beirut during a two-month stay in the spring of the same year. The main interviewees involved ten families and two individuals with ties to both countries. As I was often told about other families and their tracks, knowledge about other cases makes up a broader base of reference.

The interviews came to dwell mainly on their situation in Denmark. In contrast to my first intention of comparing the social positions of the interviewees in the two settings, Denmark and Lebanon, the outcome mainly included reflections about their position and status in Denmark. Whether interviewed in Denmark or Lebanon, the interviewees reflected upon their position in Denmark rather than Lebanon, which might have been due to me being a Dane with only limited and superficial knowledge of Lebanon, causing me to respond more to their reflections on their situation in Denmark. It might also indicate that more was at stake in their relation to Denmark than to Lebanon. Along with the bulk of the Palestinians in Denmark, they arrived in the 1980s when asylum laws were favourable and anti-immigrant expressions in public discourse were considered extreme and marginal. Since then, the admittance of newcomers from outside the EU has been restricted considerably and, during the same period, anti-immigration attitudes grew and subsequently became antiMuslim in particular. The interviewees were affected by this development to various degrees, but each of them seemed to have a bone to pick with Denmark.

In this article, I explore the narratives of location and positionality in the pros and cons of living in Lebanon and Denmark as expressed by the interviewees. I begin with a short introduction to the historical context of the transnational practice of this particular group of Palestinians and a presentation of the conceptual framework of symbolic capital and belonging. I then turn to the field material, where three patterns of transnational practice, which I have tentatively labelled commuters, returnees and frequent visitors, were prevalent in my material. I present three families and examine their positions in the social order. Next, I proceed to analyse the narratives expressed in some of the topics that the interviewees dwelled upon greatly during their interviews, namely how to be recognized as a competent parent and expectations regarding one's own gender role. To conclude I qualify the marginal position of the individuals in the case in question and discuss the pertinence of this position for transnational practice and belonging.

\section{Framing PALESTINIAN}

\section{TRANSNATIONAL PRACTICE}

The Palestinian refugees from the Lebanese civil war in the 1980s make up one particular case regarding transnational experience. According to the literature on transnational practice, migrants who renew contact with the country they once left behind usually do so in order to transform the political and economic position gained in their host country into a political and social position in their home country (Vertovec \& Cohen 1999, Levitt \& Glick Schiller 2004). Refugees who only recently have been included in the field of research of transnational practice are also returning to their home countries to take part in national rebuilding projects in post-conflict times, (see, for example, Al-Ali, Black \& Koser 2001). The Palestinians in question are only motivated by a few of these conditions, as circumstances in Lebanon do not offer Palestinians much in terms of economic opportunities or opportunities to play an active political or social role. Palestinian visi- 
tors and returnees are likely to return to rather marginal positions in what is not to be considered their home country.

The interviewees in this study were granted asylum between 1985 and 1987, or came to Denmark by way of marriage to a refugee from this period. In the middle of the 1980s, the possibilities for obtaining asylum in Denmark were favourable. To achieve accordance with UN conventions, the Alien Act was revised in 1984, making "it possible for anyone who was at the Danish border and said the magic word asylum to be let into the country to have his or her case tried" (McGuire 1992, 661). This coincided with one of the lengthiest and most violent episodes of the Lebanese civil war, the Battle of the Camps, which took place in the Palestinian camps of Beirut (Sayigh 1994). Word of Denmark's open policy travelled quickly to Lebanon. The Palestinians who arrived in Denmark during this period were recognised as genuine refugees and granted asylum on account of being stateless and because of the severe plight of Palestinians in Lebanon at the time. In 1986 the Alien Act was revised once again and the principle of 'safe country' was introduced, which meant that the asylum seeker could not have his or her case tested in Denmark if they stopped at a country that was considered safe while in transit to Denmark. This decreased the annual number of asylum applicants considerably, yet throughout the 1980s a number of Palestinians fleeing from Lebanon were granted asylum every year (McGuire 1992).

At this point, these Palestinians have now lived in Denmark for two decades. They have no share in the reconstruction of Lebanese society after the civil war. Although the civil war came to an end in 1991 and the reliability of the current level of stability can be trusted, the position of Palestinians vis-à-vis the Lebanese state and society has never been more dubious. ${ }^{2}$ Legal measures concerning the conduct of
Palestinians include severe restrictions on employment, visa restrictions, and restrictions on building (Edminster 1999). The latest legislative measure directed towards Palestinians was passed in 2001 and denied the legitimacy of property purchased by stateless individuals, which in Lebanon includes mainly Palestinian refugees (Sayigh 2001 ).

Although Palestinians who return to Lebanon as Danish citizens or with another foreign passport are not subject to similar legal restrictions, they are still considered part of the Palestinian community, which according to a large part of the majority population is to be prevented from integrating into Lebanese society. In the beginning of the 1990s, a survey found that 75 per cent of the Lebanese population opposed the permanent integration of Palestinians in their country. Before and after, Palestinians have often - in both official and unofficial quarters - been the scapegoats of the civil war and of most of the other subsequent problems of the fragile Lebanese state (Edminster 1999).

The Palestinians in question are granted far more formal rights in Denmark. By now, some of them have obtained Danish citizenship, and all of them have permanent residency, work permits, the right to vote in municipal elections, and access to wideranging social services. In light of this, the extensive transnational practice of this refugee group is puzzling and calls for further examination.

\section{SyMBOLIC CAPITAL AND BELONGING}

To a large extent, the research literature acknowledges that most individuals with an immigrant background are at any stage already and still part of networks spanning other places; transnational practice is regarded the rule rather than the exception (Vertovec \& Cohen 1996). It has also been acknowledged that the ability to relate to environments and tap into networks other 
than that of the receiving country does not necessarily constitute obstacles to integration in the receiving country and, in some cases, might even prove productive for processes of integration (see, for example, Caglar 2001, Levitt \& Glick Schiller 2004). In this article, I assume that the form and actual way of maintaining or creating connections with the country one once inhabited is in another way related to the opportunities at hand in the receiving country and especially the possibility one has of belonging.

Belonging is most often conceptualized in terms of citizenship and/or identity. Yuval-Davies argues that in addition to this an emotional dimension is relevant to the ways individuals and groups relate to and are treated by states and society (2006). Accordingly in my interviews, emotions more often than citizenship and identity rights were referred to as relevant to the choices of movement and settlement. These emotions, which do not appear as personal or individual, seem rather to resemble and be structured according to one's position in society.

Therefore, I approach the transnational practice of my interviews as position-taking, which according to Bourdieu, takes place by way of resources that can be differentiated into economic, cultural, social and symbolic capital (Bourdieu 1986, 1990). I differentiate further between bridging and bonding social capital; the former is the outcome of networks with people different from oneself, while the latter is generated by close contact with people in one's own category in terms of social and/or ethnic background (Putnam 2000). Belonging in my analysis is, in turn, tentatively understood in the same conceptual framework, i.e. belonging is related to the possession of a variety of forms of capital and the ability to convert one form into another. Through this scheme it is possible to distinguish different forms of belonging and perceived marginalization, determined by the form of capital that is available or lacking.

I approach the issue of belonging based on the expressions the interviewees used in what appear as narratives of location and positionality (Anthias 2002). These narratives reflect their position in the social order in Denmark and Lebanon respectively, and their views of where and to what they do and do not belong. Symbolic capital proved to be crucial to the perceived marginality in the narratives of the interviewees in this study. Symbolic capital is a reflection of the way one is seen by others and consists of recognition or acknowledgement from the surrounding society. This form of capital is usually a further return of other forms of capital, but the conversion of other forms of capital into symbolic capital can meet with obstacles and does not always take place (Diken 1998). These obstacles often take the form of symbolic violence, i.e. the imposing of definitions of the social world by institutions and the media (Bourdieu 1991). In this article, the concepts of symbolic capital and symbolic violence serve to make sense of the perceived marginality and the difficulties involved in establishing feelings of belonging prevalent among the interviewees.

\section{COMMUTERS, RETURNEES, VISITORS}

When asked why he and his wife, in 2001, gave up a seemingly rather successful life with good jobs and lots of social contacts in Denmark, one of the interviewees replied that anti-immigrant sentiments had grown so strong at that point that they both found it unbearable to stay on in Denmark. He elaborated:

We felt the pressure even when socializing with well-intentioned Danish friends. "Us and them" was always the subject of discussion. Why couldn't we just for once debate the tax system or environmental problems like any other group of friends? Don't misun- 
derstand me, I am not especially interested in these two subjects, I just felt the need to be accepted and respected as a completely normal and sane partner in the discussion.

This family chose to leave Denmark behind and to return to Lebanon for good. This is one of three patterns distinguishable among the ten families in my material. There is a 'returnee' pattern, such as the above family, where the family is mainly in Lebanon; second a 'frequent visitor' pattern, where the family is mainly in Denmark; and third, a 'commuter' pattern, where the family has one foot in each country. Among the ten families were two returnee families, three commuter families and five families, which can be labelled frequent visitors. Looking carefully at the positions of the families in Denmark, there are some regularities between those who follow the same pattern, and the variations between the patterns can be accounted for by describing variations in possession of capital.

The returnee family presented above possessed a fair amount of economic capital while still living in Denmark; both spouses had reasonable incomes and they owned their own home. Both had cultural capital or education in a form that was valuable in Denmark and to the extent that it could be converted into jobs. They were not short of social capital, i.e. the return of social connections, which could serve as bridging functions to important jobs and influential networks. The wife, who was also an active member of a political party, got her job as a manager in the educational sector through party contacts. The position of the husband reflects his more limited bridging social capital. Although he had held various positions on the strength of his qualifications, he had not managed to leave the 'refugee sector', which he considered unsatisfactory. They seemed to be slightly lacking in other types of networks serving bonding functions, i.e. networks with people with a simi- lar backgrounds to their own, but they were satisfied with a handful of close friends and family. When it came to symbolic capital, they felt they did not get enough recognition, although the wife especially was met with a lot of respect in her professional career and in her political work. The recognition they lacked is of another kind and is related to lifestyle more than to professional qualifications. They felt that in particular they were met with scepticism with regard to the way they wanted to bring up their children. In addition, they felt what can be labelled as symbolic violence and talked at length about feeling categorised as different. They were affected by their children developing a sense of being different from and disliked by the majority of the population. When media stories came out about the conduct of individuals with a Palestinian, Arab or Muslim background, they were annoyed by expectations from colleagues and acquaintances that they defend or denounce whatever these individuals had done.

The family I refer to as frequent visitors is the poorest of the three families in purely economic terms. The household included a wife, husband, two children and the parents of the husband. The wife and his parents were on social welfare. At the time of the interview, the husband had had work for some time at a reasonable salary, but he was only employed intermittently. The family as a unit had no opportunity to save even a small part of their income and what savings they did accumulate went to family members in Lebanon with the exception of money spent on the regular visits to Lebanon made by the wife and children and the grandparents. Their relatives in Lebanon lived under very poor conditions in the most destitute parts of a Beirut camp. The husband was not fond of long family visits, but his salary provided the tickets and presents. They lived in a small housing area in Copenhagen, where almost everybody had a minority background. The 
husband had some education gained in Lebanon, and, unlike most of his equals in the same area, he had been able to convert his education into jobs. His social capital was also relatively high in comparison with his immediate surroundings. He had bonding capital, as he was part of densely nit social networks of Palestinians in the housing area and in wider networks of relatives in and outside Denmark. In addition, he had bridging capital gained partly through some artistic activities that he was engaged in with Danes and a Danish institution and partly through employment in various projects in the framework of the municipality. He was also better off than any of the people in the families described here when it comes to symbolic capital. His artistic activities gained him much attention and respect. The rest of the family, his wife and his parents, if they are to be included, were very short of bridging social capital and of symbolic capital. They had very little contact with other people in Denmark, except their immediate neighbours. The grandparents mainly felt they were on standby when in Denmark. They were only waiting for opportunities to pay visits to relatives in Lebanon or simply for a phone call. They experienced the world outside the housing area as hostile and were puzzled by the grim picture of their fellow countrymen and other minorities they were confronted with in the Danish media.

The family I will refer to as commuters was far from being without capital. None of the spouses, however, had a regular job, and, economically, they relied on welfare and unemployment benefits. The husband possessed a technical degree, but this cultural capital turned out to have no exchange value, as it did not lead to a permanent position in his field. The wife was eager to obtain an education, but according to her 'the system', represented by her social worker, did not facilitate her ability to do so. Regarding social capital, they were well acquainted and respected in Palestinian circles in their local area and took part in various community-building associations. Thus, they possessed considerable bonding social capital, but not much bridging social capital. They were acquainted with some Danes, neighbours and fellow students of the husband, but apparently these connections did not lead to jobs. When trying to estimate their amount of symbolic capital, it is remarkable that they speak of an increasing feeling of being valueless. Like the returnee family, they spoke of increasing anti-immigrant tendencies, yet their feelings of being valueless were also related to not being able to establish a satisfying job career, and in the case of the husband, not being able to do so because of - in his view - having an ethnic background other than Danish. Moreover, the wife was very pessimistic about the future of Muslims in Denmark and her own chances as a Muslim woman to ever acquire a job.

In the Danish context cultural, economic and social capital are unequally distributed in the families presented above, and so are their abilities to convert these forms of capital into economic capital via paid work. Those with the most economic, social and cultural capital were apparently also those who took actual steps to leave Denmark behind. Those who had less economic capital but who were not lacking social and cultural capital took up a commuter practice in order to earn an income in Denmark while keeping the family in Lebanon. Those lacking most of all of these forms of capital remained in Denmark, but channelled most of the capital they managed to gather to Lebanon in one way or another.

When it comes to symbolic capital, i.e. recognition and status, few variations are seen. With the exception of the husband in the frequent visitor family (but not his wife and his parents), the possession of symbolic capital and the convertibility of any other form of capital into symbolic capital, seem to be limited to the interviewees.

The marginalisation in the material, legal 
and political fields they face in Lebanon is obvious to observers and to themselves. In Lebanon, they are also marginalised in a symbolic manner as scapegoats of the problems of the Lebanese state, and more or less excluded from the media and the political arena. Yet, the marginalisation that these Palestinians face as members of a minority population in Denmark seems to hit them just as hard. According to my interviewees, the marginalisation they experience in Denmark has to do with a perceived attack on their lifestyle and daily practices, particularly regarding the upbringing of their children and gender relations.

The strategy of all the families to confront this marginalization - regardless of their pattern of transnational practice seems to be the withdrawal of their family life from Danish society. The returnee family, the family with most resources in all respects, moved to live in Lebanon. The commuter family made an arrangement to have their family life in Lebanon and their economic life in Denmark. The last family remained in Denmark, but their family life was more or less encapsulated in their own social circles, while the elderly parents of the husband and wife mainly sought the status and recognition that they longed for outside of Denmark.

To be sure, I have no evidence that all Palestinians in Denmark follow these patterns as other coping strategies may be numerous and widespread. The hardships of obtaining symbolic capital, however, are relevant to all my interviewees regardless of their positionality and are presumably common to most Palestinians in the Danish context.

To pinpoint this marginality further, interview responses in a specific area are applicable. Remarkably, all interviewees, to some extent, reason about their transnational activity (whether it includes frequent visits, commuting or attempts to return for good) by way of concern for their children. Considerations concerning the future of their children and their ability to be competent parents offer an elaboration of the effects of the scarcity of symbolic capital on integration opportunities.

\section{TO BE RECOGNISED AS COMPETENT PARENTS}

At the time of the interviews the parents following the returnee and the commuter pattern of transnational practice were occupied with getting their children back on track by finding the right school and by helping them to catch up with the curriculum. They were engaged in finding well-reputed schools with a high academic level that did not solely prioritise academics. Catching up was reported to be demanding as well as the idea that doing so required a multitude of essential skill. Everyone had difficulties finding what they considered to be a suitable school for their children. One family decided to move their children from one school to another because the teacher practised corporal punishment at the first school. Most of the interviewees praised the Danish school system and hoped to find schools and teachers who also focused on social and artistic skills along with academic ones "as Danish schools do".

Although the most persistent argument for moving to Lebanon was that of improving the situation of one's children, the formal opportunities in the school system would allegedly not ensure improvement. Instead, though not surprisingly, the most frequently mentioned reason for fostering contact with Lebanon was to increase the contact one's children had with family members, their knowledge of religion and their language skills. In addition, some concerns considering life in Denmark were aired during interviews that made Lebanon come out as the better place of the two settings when it comes to bringing up children.

First, worries about not being able to convey religion, morals and values to one's 
children when in Denmark were presented. One couple expressed worries that their children would not become Muslims or good Muslims in Denmark. Even though most stated that this was a danger, they felt they were able to cope with it. Thus, a more moderate concern about passing on religion as expressed by a father in one of the families was more representative of the interviewees in general:

It is not impossible to bring up your children to become good Muslims in Denmark, but it is a tough job. You are up against the whole system. Here [in Beirut] we just sit down and then we listen to the prayer call - it is wonderful. In Denmark you have to choose between various groups, here everybody can just go to the mosque down at the corner. And another example, when they [his sons] get older, if we do not want them to have girlfriends, we have the sole responsibility, whereas here, the school and society as a whole share the responsibility.

This man went to Beirut for a year with his wife and their two children, not only to be close to family and relatives, but also to enjoy the support of the larger society to make his language, values and lifestyle seem normal to the children. The longing for being in accordance with one's environment and feeling comfortable with one's way of life and not under attack is equally reflected in most interview responses. The wife and mother in one of the returnee families who is not convinced that they will make it in Lebanon describes their stay as a breathing space, or a break that in all regards was needed for the parents and children alike. She, too, talked about longing for doing what you think is right for and with your children without being criticised or simply questioned about every step you take.

Second, all the parents were concerned about not being able to fulfil their own expectations of being good parents. This was mainly expressed as a matter of not being able to provide a proper model to follow. The way of paraphrasing this was often the same and is echoed in the following in the words of one mother, "The problem is not the country, it is the parents. When the parents are not working, the son watches his father lying on the couch all day long." This anxiety was always related to the role of the father, indicating that his status was an important matter to the family as a whole, and at the same time challenged by the circumstances in Denmark.

Some interviewees also reported incidents where their performance as parents was called into question more directly as well. One parent explained that:

Danish values are just better, that is what meets you all the time. They [Danish values] are presented as paradise. What is Danish is just better, for example, Danish education. And, you have to adjust to that on all levels. If your children did not know Danish children's songs before they started school, you were a bad parent.

The impression gained was that there is very limited space for bringing up your children in accordance with your own assumptions.

Third, some parents were bothered by the impact on their children of the remarks and attacks on their ethnic, cultural and religious background. One returnee family responded to the question of what made them make the decision to leave for good by saying:

It is rather complex. The children, first of all, hear all the bad things that are said. During the latest period (in Denmark) the children asked when a politician turned up on television, "Is he with us or against us"? The children are brought up with the feeling of being different.

The univocal claim that it is difficult to carve out space for fulfilling one's role as a 
competent parent and reports of persistent feelings of being under attack when dealing with one's children is striking.

\section{WEIGHING THE PROS AND CONS}

The family referred to above as a commuter family consists of Mona, Saleh ${ }^{3}$ and their two children. Saleh, who came to Denmark in the middle of the 1980s, obtained a vocational diploma, supplemented by three and a half years of study and thus became a technical engineer. In 1992 he married Mona, one of his cousins, during a visit to Lebanon and brought her to Denmark. At the time of the interviews they had two children. While still in Denmark, as mentioned above, she decided to become a kindergarten teacher. In 2000, the family moved back to Lebanon where they took up residence in a middle class area just south of Beirut where Mona's closest relatives live. Over the last 10-15 years, this branch of the family had managed to climb up the social ladder and had moved out of the camps. Saleh's part of the family, or at least his parents, was still living in a camp in Beirut. In the spring of 2002, after lengthy deliberations, the family decided to make a change once again, this time without changing their place of residence. Saleh started up a travel agency with a colleague in Denmark. He returned to Denmark in April and visited Lebanon for a short time in June, after which the whole family went to spend their summer holiday in Denmark. Their plans at the time of the interview were to keep their flat and family life as well as the schooling of the children in Beirut while making a living from a business in Denmark with Saleh continuously travelling back and forth. They have close relatives living in Denmark which include her sister and his brother. In the summer of 2002 Saleh, Mona and their children spent three months of their holiday in Mona's sister's flat in the same housing area where they also used to live.

\section{HIS CONSIDERATIONS - STATUS AS BREADWINNER}

There were many reasons for going back to Lebanon, although for Saleh, this included first and foremost the difficulties he had in finding a job. While all other students in Saleh's class at the engineering college were offered jobs before graduation, all of his applications at that time and since then had been turned down. He experienced being told that a position he applied for was already filled and then seeing a new advertisement for the same position afterwards. Once he was told by an employer that he should never expect to have a job commensurate with the level of his education, because "naturally we cannot place you as a formal superior to Danes".

After returning to Lebanon, Saleh helped his father in his restaurant in the camp. According to Saleh and Mona this job was neither satisfactory from the point of view of expectations of status, nor sufficient to provide for the family in the long run. In the end, the opportunity of establishing a career in Denmark while keeping his wife and children in a flat in Lebanon was the most fulfilling of the opportunities available. The hardships of commuting and being away from his family seemed to be outweighed by the ability to become a decent breadwinner and thereby gaining not only a proper income but also symbolic capital.

His main consideration was his role as the breadwinner of the family. This was, in turn, important for his ability to live up to his own expectations of providing a good role model for his children. The humiliating episodes he had experienced while looking for a job in Denmark were a critical aspect for him regarding the choice to move to Lebanon.

\section{HER CONSIDERATIONS -} FREEDOM OF MOVEMENT

Mona's considerations were of another 
kind. When interviewed a year after their return to Lebanon, Mona was bothered by the attempts made by her family to control her and said:

They interfere with my movements. If I want to go somewhere they say, "Uh, are you going alone?" In the beginning it was difficult for them, but now they are getting used to it. When I was in Denmark I went alone wherever I wanted to go, nobody asked and nobody interfered.

'They' were mainly her sister and her father in law, who were not yet used to her making her own decisions in all matters. She was not allowed to stay in her and her husband's flat alone with the children when he was doing business in Denmark, but had to stay at her sister's place some 100 metres up the street. She was dissatisfied with this and other similar arrangements. Nevertheless, when she expresses great satisfaction with being back in Lebanon, it is tempting to interpret it as her sacrificing her own needs in order to do what is good for her family. But, when weighing Mona's pros and cons, it does not seem to be a sacrifice. Although she was pleased with the lack of restrictions on her whereabouts in Denmark, Mona alludes to other problems in her daily life. She enjoyed the liberty of moving around freely, but she did not feel altogether like a liberated woman in Denmark either. She explained:

When you wear a headscarf you have to listen to a lot of things. They ask about everything! They think we wear it when we are asleep.

Once I was asked, "Is your husband allowed to see your hair?" Come on, I have kids with $\operatorname{him}(\ldots)$. And then they ask, "Why are you hiding? Why do you walk around like a tent?" And some people spit on you.

Mona perceived this harassment and categorisation, which are forms of symbolic violence, as threats against her autonomy.
This aspect seemed to be rather crucial for Mona when she was making up her mind about the advantages and disadvantages of the two different settings. The rather extensive restrictions put on her daily movements in Lebanon seem to be easier to deal with than the stream of small questions and expressions of disapproval in Denmark. In Lebanon, she has her victories and her defeats, but she knows how to work with the restrictions that exist. She is at least experiencing that her family is changing their attitude towards her - that they are "getting used to it" - and she believes she might as well benefit from the on-going negotiation and struggle for a broader independence that women have gained in Beirut in recent decades. By comparison, the categorisation she experiences in Denmark is diffuse and difficult to cope with. Mona seems to be without weapons and strategies to cope with the symbolic violence found in Danish society.

\section{CONCLUDING REMARKS}

To sum up, the transnational practice of the families in this study follow three distinguishable patterns, returnee, commuter and frequent visitor. Strikingly, all the families, regardless of pattern, albeit by way of different strategies, tend to withdraw their family life from the Danish majority society. They divide their lives into work, on the one hand, and family building on the other, and they arrange these tasks across borders according to opportunity structures in the two countries.

The aim of the withdrawal of family life is seemingly to find recognition for one's own way of life. Because they feel that their family life is under attack from the Danish majority society, the interviewees opt for recognition elsewhere. During interviews, men as well as women brought up their role as parents; many felt misunderstood in their intentions and all had difficulties in coming to terms with their own perfor- 
mance as a parent in their new country. They felt that their gender practices were similarly under attack.

The aim of obtaining recognition outside the Danish majority society does not seem to be equal to a wish to conform to traditional modes of being, and the families did not altogether denounce norms associated with Denmark. Remarkably, the parents in the commuter and returnee families returned as demanding parents. They required high standards, creativity and democratic structures in their children's schools, which are norms they associated with the Danish school system. With respect to gender, the father's role as the breadwinner seems to be given considerable weight by both women and men and was not questioned or relativised by any of the interviewees. While narratives on the position of men tend to conform to a traditional representation of a husband, the narratives on the position of women seem to be more open and seemingly in a process of change. At least in the case of Mona, the rights of a woman to make her own decisions, to move around freely and to work outside the home thrive in her transnational activity.

In both Lebanon and Denmark, the Palestinians in question seem to be symbolically marginalised. In weighing their pros and cons, Lebanon - in spite of severe formal restrictions - tends to come out as the most promising place of the two in terms of achieving symbolic capital. The marginalisation they face in Denmark has to do with a lack of recognition of their lifestyle. Diffuse and difficult to cope with, the marginalisation makes it difficult to achieve a feeling of belonging in Denmark. One s 'symbolic capital account' seems to evoke emotions that condition belonging and have a large impact on the transnational practice unfolded by the people interviewed.

It remains to be examined whether the pertinence of emotions and symbolic capital for transnational practice and belonging have a wider bearing in relation to other ethnic minority groups in marginal positions. For the group in question, the Palestinians who came to Denmark from Lebanon in the mid-1980s, the symbolic marginalisation experienced in Denmark adds to their restlessness and the ongoing search for new coping strategies that inevitably condition life in the Palestinian diaspora.

\section{Notes}

1. The number of Palestinians in Denmark is subject to uncertainty, since census practices have been inconsistent and subject to change. Over time, Palestinians have been registered as stateless or as Lebanese, Jordanian, etc., according to their former host country.

2. Titles of articles and books on Palestinians in Lebanon from the post-war period capture this position: Too many enemies (Sayigh 1994), Trapped on all sides (Edminster 1999), Palestinian Refugees in Lebanon: The Walls of History are closing in (Drake 2000), Exile without refuge (Sørvig 2001), "Palestinian Refugees in Lebanon: No Work, No Space, No Future" (Sayigh 2001). These works mainly describe the legal position of Palestinians in Lebanon.

3 . The names used are pseudonyms and some details about this and other families have been changed slightly to protect their identities.

\section{REFERENCES}

- Al-Ali, Nadje; Black, Richard \& Koser, Khalid (2001): "Refugees and Transnationalism: The Experience of Bosnians and Eritreans in Europe", in Journal of Ethnic and Migration Studies 2001/4.

- Anthias, Floya (2002): "Where do I belong? Narrating collective identity and translocational positionality", in Ethnicities 2002/4.

- Bourdieu, Pierre (1986): "The Forms of Capital”, in Richardson, John (ed.): Handbook of Theory and Research for the Sociology of Education.

Greenwood Press, New York.

- Bourdieu, Pierre (1990): The Logic of Practice.

Polity Press, Cambridge.

- Bourdieu, Pierre (1991): Language and Symbolic Power. Polity Press, Cambridge. 
- Caglar, Aisha (2001): "Constraining Metaphors and the Transnationalisation of Spaces in Berlin", in Journal of Ethnic and Migration Studies 2001/4.

- Dansk Flygtningehjelp (2004): Drømmen om Palestina. Flygtninge, baggrund, historie. Dansk Flygtningehjælp, København.

- Diken, Bülent (1998): Strangers, Ambivalence and Social Theory. Ashgate Publishing, Brookfield VT.

- Drake, Laura (2000): Palestinian Refugees in Lebanon: The Walls of History are closing in. Washington Report on Middle East affairs, American Educational Trust, January/February.

- Edminster, Steven (1999): Trapped on All Sides. The Marginalization of Palestinian Refugees in Lebanon. Immigration and Refugee Services of America.

- Glick Schiller, Nina; Basch, Linda \& Blanc-Szanton, Christina (1999): "Transnationalism: A New Analytic Framework for Understanding Migration", in Steven Vertovec \& Robin Cohen (eds.): Migration, Diasporas, and Transnationalism. Edward Elgar Publishing, Cheltenham, Northhampton.

- Isotalo, Riina (2005): Many Routes to Palestine. The Palestinian Return, Forged Transnationalism and Gender. Institute of Development Studies, University of Helsinki, Helsinki.
. Levitt, Peggy \& Glick Schiller, Nina (2004):

"Conceptualizing Simultaneity: A Transnational Social Field Perspective on Society", in The International Migration Review 2004/3.

- McGuire, Brian (1992): "Lebanese Asylum Applicants in Denmark 1985-1988: Political

Refugees or War Emigrants?" in Albert Hourani \& Mehdi Shehadi (eds.): The Lebanese in the World: A Century of Emigration. I.B. Tauris, London. - Putnam, Robert (2000): Bowling Alone: The Collapse and Revival of American Community. Simon \& Schuster, New York.

- Sayigh, Rosemary (1994): Too Many Enemies. The Palestinian Experience in Lebanon. Zed Books, London.

- Sayigh, Rosemary (2001): "Palestinian Refugees in Lebanon: No Work, No Space, No Future", Middle East International, 10 August: 22-24. - Sørvig, Bendik (2001): Exile without Refuge. Experiences and Practices of Exile among Young Palestinian Camp Refugees in Beirut. M. Phil. thesis, Human Geography, University of Oslo, Oslo. - Vertovec, Steven \& Cohen, Robin (eds.) (1999): Migration, Diasporas, and Transnationalism. Edward Elgar Publishing, Cheltenham, Northhampton.

Lene Kofoed Rasmussen, ph.d. 